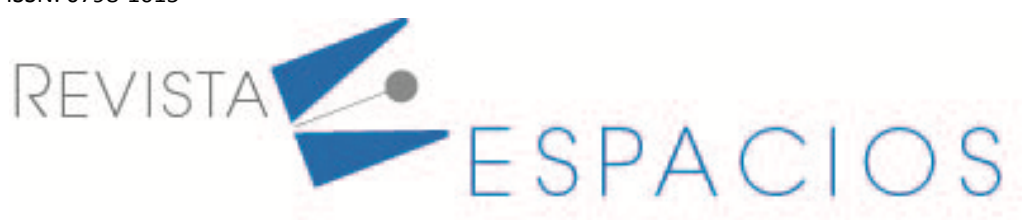

\title{
Stress psychology and its analysis from artificial intelligence
}

\section{Psicología del Estrés y su análisis desde la Inteligencia artificial}

\author{
SUÁREZ, Franyelit M. ${ }^{1}$ \\ ORTIZ, LUZ E. ${ }^{2}$ \\ ROSALES, Luis D. ${ }^{3}$
}

\begin{abstract}
A review of emotions from cognitive brain processes is presented, taking into account some experimental neurobiological studies. Sensory systems, physiological reactions of the central nervous system, and emotional stimuli are evaluated. It is evident that subjective expressions and physical reactions of emotions are conditioned to social patterns, family customs and mainly to moral stereotypes of people. Artificial intelligence is used, with state vector machine for the pro-cessing of human biological signals. Among the observed characteristics, self-sanctioning emo-tions and those of empathy with the other prevail. Finally it was possible to recognize that the restriction of emotions in people can cause psychological behaviors that harm their relationship with the environment. It produces antisocial behaviors, lack of understanding of the feelings of others, breach of the rules, among other activities and social standards.

key words: artificial intelligence, human emotions, medical application, occupational health

\section{Resumen}

Se presenta una revisión de las emociones de los procesos cognitivos del cerebro, teniendo en cuenta algunos estudios neurobiológicos experimentales. Se evalúan los sistemas sensoriales, las reacciones fisiológicas del sistema nervioso central y los estímulos emocionales. Es evidente que las expresiones subjetivas y las reacciones físicas de las emociones están condicionadas a los patrones sociales, las costumbres familiares y principalmente a los estereotipos morales de las personas. Se utiliza inteligencia artificial, con máquinas de vectores de estado para el procesamiento de señales biológicas humanas. Entre las características observadas, prevalecen las emociones autoritativas y las de empatía con el otro. Finalmente, fue posible reconocer que la restricción de las emociones en las personas puede causar comportamientos psicológicos que dañan su relación con el medio ambiente. Produce comportamientos antisociales, falta de comprensión de los sentimientos de los demás, incumplimiento de las normas, entre otras actividades y estándares sociales.

Palabras clave: inteligencia artificial, emociones humanas, aplicaciones médicas, salud ocupacional.
\end{abstract}

\section{Introduction}

Human emotional states are a condition of the sub conscious (Ibañez, 2009), and these emotions characterize people's behavior and condition them to their personali-ties, making them affective, or non-affective, expressive or non-expressive people, and thus defining the multiple personalities and the different characters. These par-

\footnotetext{
${ }^{1}$ Docente-Investigadora. Facultad de Ingeniería y Ciencias Aplicadas. Universidad de las Américas (UDLA). Franyelit.suarez@udla.edu.ec

2 Directora de Carrera de Psicología Industrial. Facultad de Ciencias Psicológicas. Universidad Central del Ecuador (UCE). leortize@uce.edu.ec

${ }^{3}$ Coordinador de Doctorado, Universidad Politécnica de Venezuela, UNEXPO, Puerto Ordaz, luis.rosales2@gmail.com
} 
ticularities are characteristic of the person, and depending on other social, cultural, family factors, among others, may condition them to their social or labor perfor-mance (Palacios, 2017).

Human emotions were studied for the first time in 1872 (Fernández-Berrocal, 2009), when the scientist Charles Darwin focused his studies on the analysis of emo-tions, managing to describe them as a non-exclusive condition of humans. In his research the scientist managed to define two important aspects of emotions; They are innate and they are universal. With this he confirmed that emotions do not de-pend on any specific geographical area, nor do they depend on race, or any other external aspect, but on human nature itself. The scientist stressed that the face is one of the greatest reflectors of emotions, and that this determines the reflection of the personality and individual characteristics of people (Montagu, 1959). Other authors (Harlow \& Harlow, 1962), (Reite \& Short, 1981) also affirm that crying and that the smile are exclusive to humans and that they are not present in the emotional mani-festations of other species.

Social and cultural conditions are decisive for the manifestation of emotions, and with that human expressions and attitudes are added, (Palacios, 2017), (Surrallés, 2005), (Bourdin, 2016), giving rise to people's behavior. Emotions can be intense or mild, and depending on how often they occur they can cause significant changes in behavior, which can significantly affect people's mental health, creating possible addictions that trigger stress (Moure, 2011).

The manifestations of stress are presented according to the self-demands of people or the demands of the environment, which may well be labor or social (Naranjo M. , 2009). Modernism and new ways of focusing the quality of life influence people's expectations, which lead them to seek new social goals, which to be reached affect the emotional state of people and trigger health problems (Naranjo M. , 2009), (Martínez \& Díaz, 2007).

Stress stimuli are those situations that trigger stress, which can produce important changes in the body, activating the hypothalamic-pituitary-adrenal axis and the vegetative nervous system, (Sánchez \& Vaquero, 2008), (González \& Landero, 2006), this activation produces the release of hormones, which may well cause negative or positive aspects in people (Berrío \& Mazo, 2011), (Maslach \& Pines, 1977). The manifestations of stress are presented through emotions, which may be associated with the adaptation to the change that the person may have be-fore different stressors. (Berrío \& Mazo, 2011), (Rubio, Guerrero, \& Castro, 2003).

The adrenal gland is responsible for regulating many aspects of everyday life, including carbohydrate regulation, immune response, blood pressure, electrolytes and sexual characteristics. Thus, the adrenal cortex produces glucocorticoids, mineralo-corticoids and antrogens, which add to the body's daily regulatory process (Domínguez \& Olvera, 2006), (Lavalle-González, y otros, 2011). In addition, the hypothalamic-pituitary-adrenal axis has an important participation in the stress res-ponse, achieving cortisol production.

The study of emotions is linked to stress, and their effects are involved at the same time with the mental and physical health of people (Lavalle-González, y otros, 2011), since situations of constant stress can trigger anxiety, depression, behavior disorders and situations personnel that can affect the relationship with the environment, caus-ing family, social and work problems (Naranjo M. , 2009).

Companies and organizations are increasingly demanding, and increasingly expect greater results from their employees (Flórez, 2014), causing a significant level of stress on workers, trying to improve their profiles to give more effective and effective responses in their workplace However, this burden of occupations, performance, rapid responses, can cause occupational diseases, which will be explicit in the level of stress in people, and can be seen in problems of high blood pressure, skin problems, gastro-intestinal problems. (Moure, 2011), (LavalleGonzález, y otros, 2011)- (Slipak, 1991). This type of health problems will not only affect the workers, but will also affect the productive process of the companies, product of labor absenteeism, the rotation of qualified 
personnel, among others circumstances that will cause problems in the organizations, product of collective stress (Antón, 2013), (Naranjo M. , 2009), (Sánchez \& Maldonado, 2003).

This paper presents an analysis of the methods of detection of emotions by analysis of facial physiognomy and by voice analysis, both using artificial intelligence, with state vector machine. The developed methods allow to detect emotions with different human variables: face and voice spectrum. Artificial intelligence allows an effective and rapid detection of emotions, and each of them offers advantages for an effective classification of stress in people.

This work consists of four sections: In the first, a brief introduction to the process of human emotions has been described, in the second, theoretical aspects that underlie this research will be addressed, in the third, the methodology will be considered, and in the fourth, the results will be presented. Finally, the conclusions will be described.

\section{Methodology}

The organs of the respiratory and digestive systems, which are controlled by the central nervous system, are involved in the projection process of the voice (Sánchez \& Pérez, 2007). The excitation generated in the vocal cords is propagated through the pharynx, the oral cavity and the nasal cavity (Sánchez \& Pérez, 2007), (Vargas., 2003). These cavities determine the acoustic characteristics of the voice (Cárdenas., Ceballos., Shang-Hsueh., Pavez., \& Terrisse., 2010).

Duque and Morales (Sánchez \& Pérez, 2007) affirm that there is a close relationship between the characteristics of the voice and the emotional states of people. Some investigations (Roldan., 1998), (Núñez, Cortéz, \& Suárez., 2006), have shown that various aspects of people's physical and emotional state, including age, sex, intelligence level, physical appearance and personality, can be identified only with the voice.

Figure 1

Relationship of voice to emotional states



Thanks to recent studies (J.González., T.Cervera., \& J.Miralles., 2002), it has been possible to ensure that some of the components of the voice are characteristic for expressing emotions, among which we can mention:

- The fundamental frequency.

- The duration time.

- The quality of the voice. 
Of the multiple methods that exist for the recognition of emotions (Acevedo \& Luca, 2000), (Valderrama \& Ulloa, 2011), (Ibañez, 2009) the one proposed in (Ibañez, 2009), presents more than a good performance, its accuracy analysis considering multiple stages of training and evaluation for 7 basic emotions such as: anger, contempt, disgust, fear, happiness, neutral, sadness.

\section{Results}

Stress can be caused by different causes, which are called stress stimuli. These stimuli can be presented in different areas of daily life, whether in work, academic, family or social situations in general (Karasek, 1979). Most of the manifestations of stress occur in work environments, this because of the demands of globalization, new technologies, new requirements to respond to spaces of business competence (Karasek, 1979)- (Peiró, Estrés Laboral, Liderazgo y Salud Organizacional, 2008). Social changes, socio-political conditions and new impacts on the labor market greatly influence the proliferation of stress situations in people (Peiró \& Rodríguez, Estrés laboral, liderazgo y salud organizacional., 2008).

Some authors (Trianes, y otros, 2009), have developed different mechanisms to measure stress, using specific questionnaires with 25 items; referred to health, education, family. The results showed that emotions are significant in the manifestations of stress, and that this in turn significantly affects the health of people and of more diseases (Mcade, Lumley, \& Casey, 2001).

Suárez and Rosales (Suárez \& Rosales, Algoritmo para la evaluación del modelo dinámico del estrés, 2019) state that stress can be represented from a set of mathematical variables that relate stress and health status, and in these it is possible to determine that stressors and the frequency or permanence of they are triggers of stress, and that this condition is in turn triggers of serious health problems, so it is very important to pay attention to stressors to avoid their continuous presence.

Knowing the possible consequences of stress, electronic systems have been developed for analysis (García, Garzón, \& Camargo, 2011), where physiological variables have been considered for their detection, including galvanic impedance of the skin, blood pressure, heart rate, blood volume, between others. The study revealed that non-invasive methods are the most appropriate for measurement, and are also simpler for data processing.

Other authors (Acevedo \& Luca, 2000) have developed a digital system that in addition to considering the variables of muscle tension, skin conductance and respiration, has taken into account the inclusion of a stress test and cortisol and prolactin values. In this study, the importance of stress in people has been assessed and it has been concluded that the Stress-Disease scale must be validated by experts from the medical area, who demonstrate that the System does not present a total success in the determination of stress, but the results are relative.

Artificial intelligence in medical processes contributes significantly to signal processing, data processing, automated learning, among others (Martínez \& Goddard, 2001), (Valderrama \& Ulloa, 2011). These intelligent algorithms contribute to formulating more appropriate solutions, more optimal processing times and a smaller margin of error than in classical processes (Alfonso, Muñoz, López, \& Caicedo, 2007).

The Support Vector Machine (SVM) is widely used for the classification of variables, which have been discriminated against for a specific purpose. This type of method constructs a hyperplane to delimit the space between both categories. Some authors (Mosquera, Castrillón, \& Parra, 2018), have developed support vector machines for the psychosocial verification of teachers, these studies showed that the use of SVM is useful for the treatment of human physiological information, achieving efficiencies in $96.3 \%$. 
A comparative process of the detection of emotions in people is carried out, in order to estimate the stress present in them. The facial image characterization method was used, using a vector support machine, and evaluating the process with a population of 343 images with different emotions, which are linked to certain expressions such as anger, disgust, fear, joy, sadness, surprise and finally the absence of emotions. For this process, The Histogram of Oriented Gradients (HOG) and K-Nearest Neighbors (KNN) are used because it yields a precision value of $71.42 \%$, however, with the HOG and SVM it yields a precision value of $75 \%$ with the KDEF base. The HOG algorithm with the KNN and with the MUG base yields $65.71 \%$. Figure 2, describes the process performed for facial image classification.

Figure 2

Face Image Classification Process

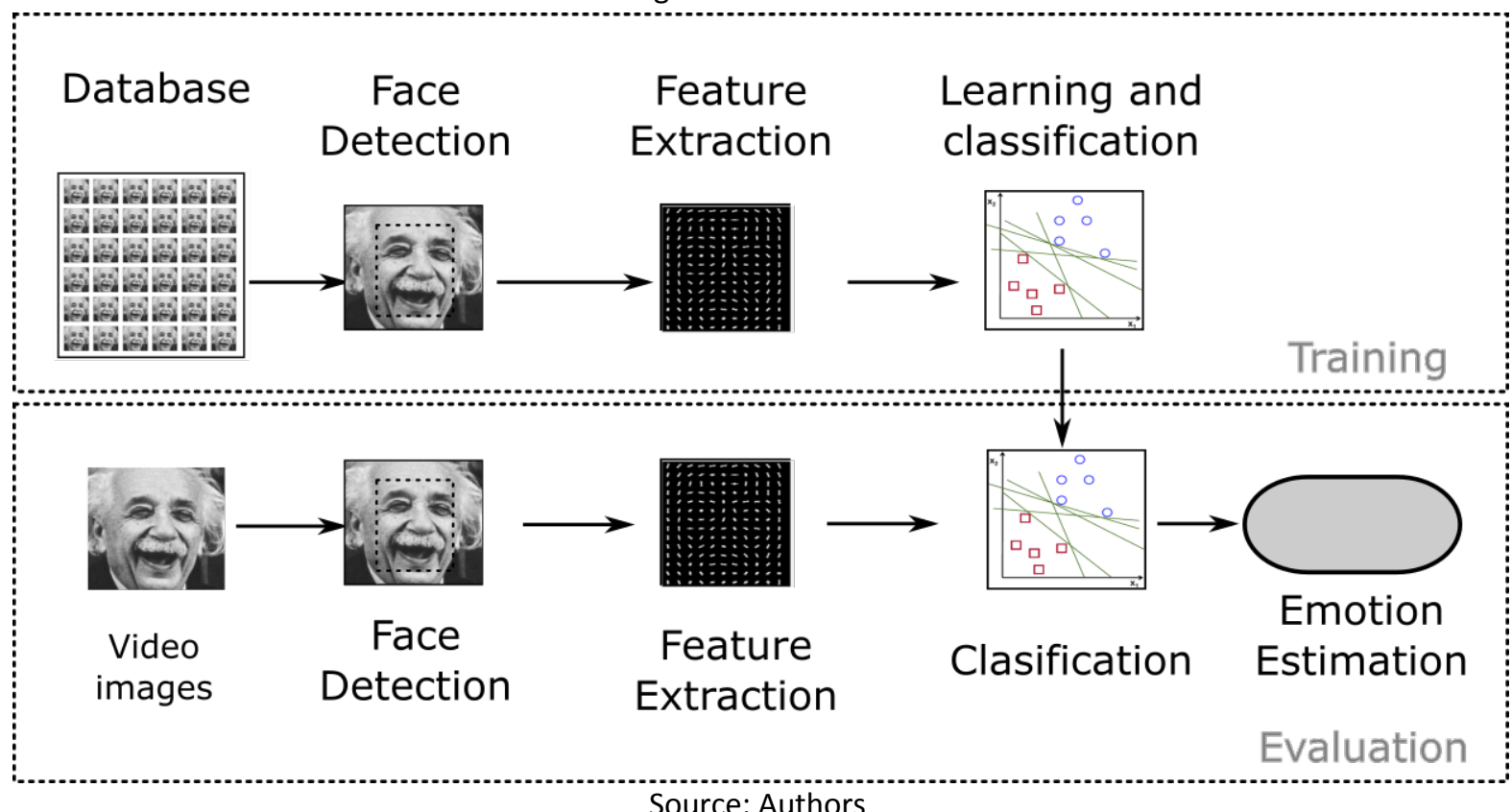

The diagram shown in Figure 2, provides information on the process performed for the classification of emotions. It has been considered a set of images that represent different emotions, and these are processed by an image normalization algorithm, to then be worked with a HOG that allows the training process, finally the SVM classifier perform the last stage together with an algorithm KNN. The System showed a success rate of $96.13 \%$.

On the other hand, an analysis of the emotions is carried out from the voice, for which we worked with the frequency of the voice spectrum. For this, the central coefficients in Mel frequencies are used, which focuses on human auditory perception. In the process, filtering is done to discard information that is not relevant, such as background noise, external noise, among others. This type of process was proposed by Davis and Mermelstein (Davis \& Mermelteins, 1980) in the last century, since then they are the fundamental basis for scientific argumentation in voice recognition.

Figure 3, shows the human voice classification process. For this, 535 voice spectra were used, representing different emotions. For this, a reading process was used by the evaluated person, in order to perceive and discriminate the voice of the same. 
Figure 3.

Voice Processing Diagram

TRAINING - DATABASE

CLUSTERIZATION

LABELED DATABASE

INCREASED DATABASE

SETS FOR TRAINING AND VALIDATION
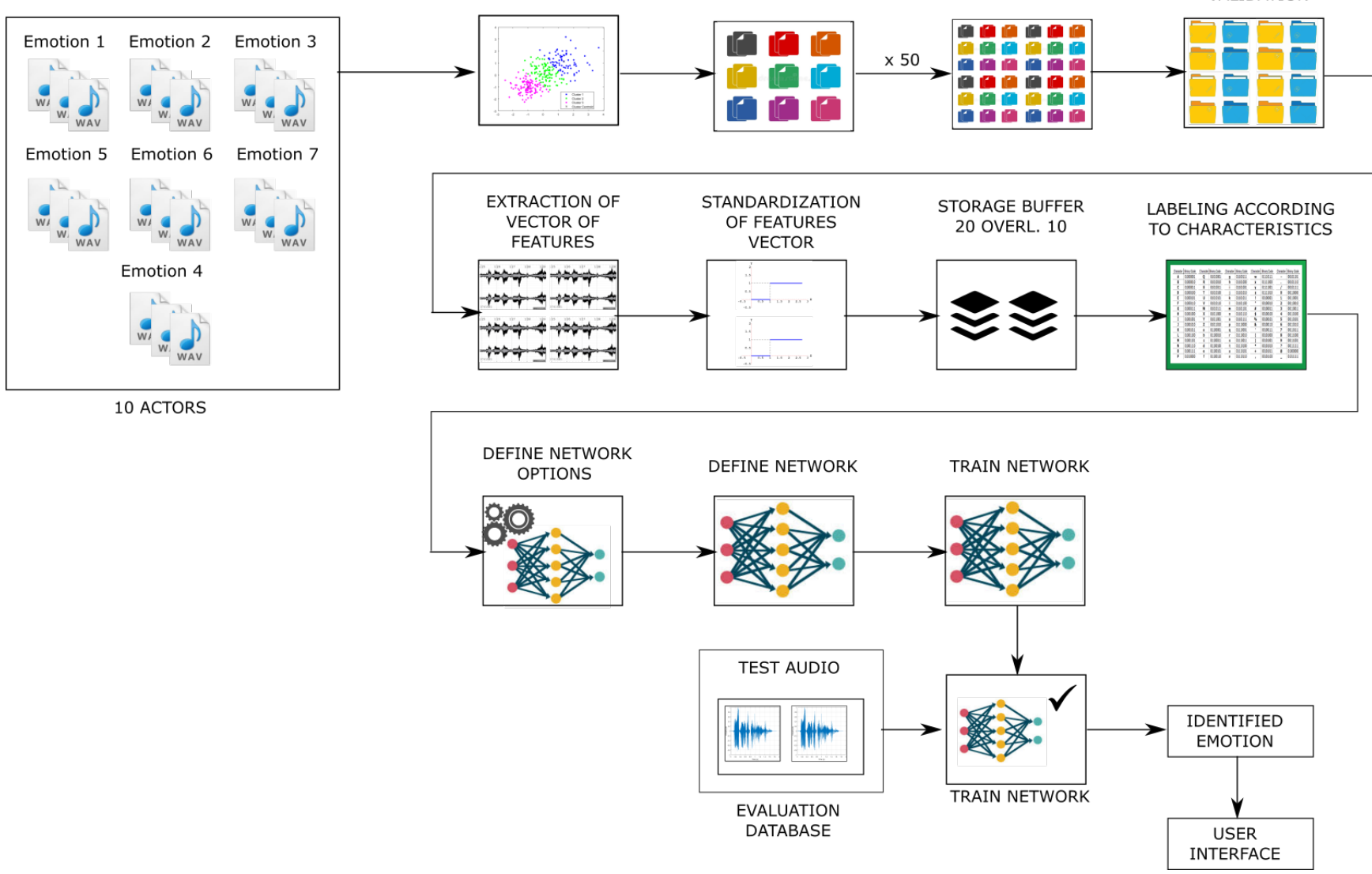

Source: Authors

Voice frequency analysis is one of the fundamental aspects in the determination of human emotions (Antón, 2013), (Cárdenas., Ceballos., Shang-Hsueh., Pavez., \& Terrisse., 2010), (Giraldo. \& Quintero., 2010). The central coefficients in Mel frequencies, allow to represent the voice spectrum and analyze it using the Fourier Transform by windows, which opens $30 \mathrm{~ms}$ spaces without overlapping. A bi-directional dependent reading network is used for natural language recognition. The results showed that the percentage of success with voice recognition was $79.6 \%$.

It was evident that both methods are appropriate for the classification of emotions, these being fundamental for the determination of stress in people. However, face classification is $16.53 \%$ more effective, making this method provide a greater contribution to the stress validation process.

Once the process of classification of variables has been achieved, it is possible to suggest that a Stress Classification System will require a third variable that allows the equilibrium of appreciation of the results and the stress classification process to be more optimal. Stress can be classified taking into account some aspects of people, these in turn are innate, are not modifiable by choice.

\section{Conclusions}

Once the methodology for characterizing emotions is evaluated, using face classification and voice classification, both taking into account vector support machine, it is possible to mention the following conclusions: 
Emotions are innate characteristics of people, which allow them to express themselves according to the conceptions of each individual, the same situation is not appreciable in the same way by two people, since the perception is conditioned to the individual particularities, which can be the culture, family formation, social conditions and the environment in general.

Emotions allow people to identify stress situations in people, which can manifest themselves at different levels and that can affect people's health status, their attitudes and their work and social performance.

Stress stimuli trigger stress situations and as long as these occur regularly and frequently, stress will continue to have an effect on people's health status, which can trigger severe illnesses, social attitudes that can cause behavioral problems, work problems and even death.

The classification of emotions by face, offers more optimal results for the determination of stress in people, the percentage of success results in $96.13 \%$ which could be improved if a broader database is considered with people not trained for it, who can Express your different emotions spontaneously. In addition, convergence with another additional method could be considered, for the limitation of the region of analysis for each figure, so that the non-relevant areas can be discriminated and the process made more effective.

The classification of emotions by voice, is known as a fairly effective method, however, it did not yield optimal results to ensure emotional state, creating spaces of uncertainty, which is not convenient as a single analysis in the classification of emotions and in consequence of stress

The results found reveal that it is essential that some additional variable be included for the assessment of emotions in people, so that it is possible to triangulate the information and achieve more optimal results.

\section{Bibliographic References}

Acevedo, M., \& Luca, A. D. (2000). Sistema Digital para Medir el Nivel de Estrés en un ser Humano. Mexico: Instituto Politécnico Nacional.

Alfonso, W., Muñoz, M., López, E., \& Caicedo, E. (2007). Optimización de funciones inspiradas en el comprotamiento de búsqueda de néctar en abejas. Congreso Internacional de Inteligencia Computacional. Colombia.

Antón, E. (2013). Estrés laboral y variables biomédicas. Revista My Science Work.

Berrío, N., \& Mazo, R. (2011). Estrés Académico. Revista Dialnet, 3(2).

Bourdin, G. (2016). antropology of the emotions: cocepts and trends. Revista de Ciencias Antropológicas(67), 55-74.

Cárdenas., I., Ceballos., H., Shang-Hsueh., L., Pavez., W., \& Terrisse., C. (2010). Estudio acústico de la variación interlocutor en sujetos hablantes nativos del español de Santiago de Chile. . Chile: Tesis de Grado. Universidad de Chile.

Davis, S., \& Mermelteins, P. (1980). MelSpectrogram: a MFCC. Recuperado el 2020, de http://www.fon.hum.uva.nl/praat/manual/MelSpectrogram_To_MFCC__html

Domínguez, B., \& Olvera, Y. (2006). Estados emocionales negativos; dolor crónico y estrés. Rev. Ciencias, 67-75.

Fernández-Berrocal, P. (2009). Darwin y el misterio de las emociones. Málaga: UMA. SEDOC.

Flórez, C. (2014). Estrés laboral en empresas de producción. Colombia: Universidad de Manizales. 
García, S., Garzón, L., \& Camargo, L. (2011). Revisión de dispositivos electrónicos para la determinación de estrés a partir de variables fisiológicas. Visión Electrónica, 5(1), 114-122.

Giraldo., D., \& Quintero., O. (2010). Análisis de señales de audio utilizando la transformada de Gabor. Recuperado el junio de 2019 , de https://repository.eafit.edu.co/.../29\%20Analisis_de_senales_audio_utilizando_transformada

González, M., \& Landero, R. (2006). Síntomas psicosomáticos y teoría transaccional del estrés. Revista Ansiedad y estrés, 12(1), 45-61.

Harlow, H., \& Harlow, M. (1962). Social Deprivation in Monkey. Scientific Americam(207), 136-146.

Ibañez, C. (2009). Charles Darwin. Sociedad, 38-42.

J.González., T.Cervera., \& J.Miralles. (2002). Análisis acústico de la voz: Fiabilidad de un conjunto de parámetros multidimensionales. . 53(4), 256-268.

Karasek, R. (1979). Job demands, job decision latitude, and mental strain. Implications for job redesign. Rev. Administrative Science, Quaterly(24), 285-308.

Lavalle-González, F., Villarreal-Pérez, J., González, G., Montes-Villarreal, M., Mancillas-Adame, L., Tamez-Pérez, H., \& al., e. (2011). Validación de la medición de cortisol en saliva de una población de adultos jóvenes. Rev. Endocrinología y Nutrición, 19(4), 146-158.

Lavalle-González, F., Villarreal-Pérez, J., González-González, G., Montes-Villarreal, J., Mancillas-Adame, L., Tamez-Pérez, H., . . V Valencia-García, J. (2011). Validación de la medición de cortisol en saliva de una población de adultos jóvenes. Revista de endocrinología y nutrición., 19(4), 146-148.

Martínez, A., \& Goddard, J. (2001). Definición de una red neuronal para la clasificación por medio de un programa evolutivo. Rev Mexicana de ingeniería biomédica., XXII(1), 4-11.

Martínez, E., \& Díaz, D. (2007). Una aproximación psicosocial al estrés escolar. Educación y Educadores, 10(2).

Maslach, C., \& Pines, A. (1977). The burnout syndrome in day care setting. Rev. Child care quarterly, 62, 100113.

Mcade, J., Lumley, M., \& Casey, R. (2001). Stress, emotional skill,and Illness in children: The importance of distinguishing between Chil-dren's and Parents' Reports of Illness. Journal of Child Psychology andPsychiatry and Allied Disciplines, 42, 405-412.

Montagu, A. (1959). Natural Selection and the Origin and Evolution of Weeping in Man. Science(130), 15721573.

Mosquera, R., Castrillón, O., \& Parra, L. (2018). Máquinas de soporte vectorial, clasificador Naïve Bayes y algoritmos genéticos para la predicción de riesgos psicosociales en docentes de colegios públicos colombianos. Revista información tecnológica, 29(6), 153-162.

Moure, P. (2011). De lo psicológico a lo fisiológico en la relación entre emociones y salud. Revista Psicología Científica, 13(19), 1-8.

Naranjo, M. (2009). Una revisión teórica sobre el estrés y algunos aspectos relevantes de este en el ámbito educativo. Revista Educación, 33(2), 171-190. 
Núñez, F., Cortéz, P., \& Suárez., C. (2006). Índice de incapacidad vocal: predictivos. Acta Otorrinolaringol, 57, 101-108.

Palacios, D. (2017). Contribución al estudio de selección de parámetros para identificación de estrés en la voz. España: Universidad Politécnica de Madrid.

Peiró, J. (2008). Estrés Laboral, Liderazgo y Salud Organizacional. Rev. Papeles del psicólogo, 29(1), 68-82.

Peiró, J., \& Rodríguez, I. (2008). Estrés laboral, liderazgo y salud organizacional. Rev. Papeles del psicólogo, 29(1), 68-82.

Reite, M., \& Short, R. (1981). Attachmente, loss and depression. Journal of Child Psychology and Psychiatr(2), 141-170.

Roldan., E. (1998). Calidad y dinámica de la voz en grupos sociales en la ciudad de Valdivia (Chile). . Estudios Fisiológicos., 33, 111-118.

Rubio, J., Guerrero, E., \& Castro, F. (2003). Fuentes de estrés, síndrome de Bo¿urnout y actitudes disfuncionales de orientadores de institutos de eneseñanza secundaria. España: Universidad de Extremadura.

Sánchez, A., \& Vaquero, M. (2008). Burnout, variables fisiológicas y antropométricas: un estudio en el profesorado. Revista medicina y seguridad en el trabajo, 54(210).

Sánchez, C. D., \& Pérez, M. M. (2007). Caracterización de voz empleando análisis tiempo-frecuencia aplicada al reconocimiento de emociones. Pereira.: Trabajo de grado. Universidad tecnológica de Pereira.

Sánchez, M., \& Maldonado, L. (2003). Estrés en docentes universitarios. Revista de Ciencias Sociales, IX(2), 323335.

Slipak, O. (1991). Estrés laboral. Revista Psicología y Psiquiatría.

Suárez, F., \& Rosales, L. (2018). Artificial neural network for the evaluation of vital signs. Universidad, Ciencia y Tecnología, 22(89).

Suárez, F., \& Rosales, L. (2019). Algoritmo para la evaluación del modelo dinámico del estrés. Revista Espirales, 37-45.

Surrallés, A. (2005). Afectividad y epistemología de las ciencias huamanas. Revista de Antropología Iberoamericana, 1-15.

Trianes, M., Blanca, M., Fernández, F., Escobar, M., Maldonado, E., \& Muñoz, Á. (2009). Evaluación del estrés infantil: Inventario Infantil de Estresores. Rev. Psicothema, 21(4), 598-603.

Valderrama, E., \& Ulloa, G. (2011). Análisis espectral de parámetros fisiológicos para la detección de emociones. Rev. Sistemas y Telemática, 10(20), 27-49.

Vargas., F. (2003). Selección de características en el análisis acústico de voces. . Colombia: Masters Thesis, Universidad Nacional de Manizales.

Wierzbicka, A. (1986). Human Emotions: Universal or Culture-Specific? . American Anthropologist, 88(3), 584594.

Esta obra está bajo una Licencia Creative Commons Attribución-NoCommercial 4.0 International

(cc) BY-NC 